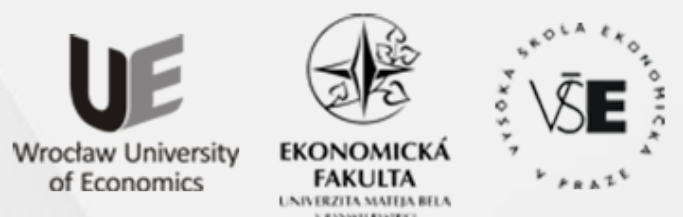

Conference Proceedings

Full TeXT PAPERS

edited by

Zofia Rusnak and Beata Zmyślona

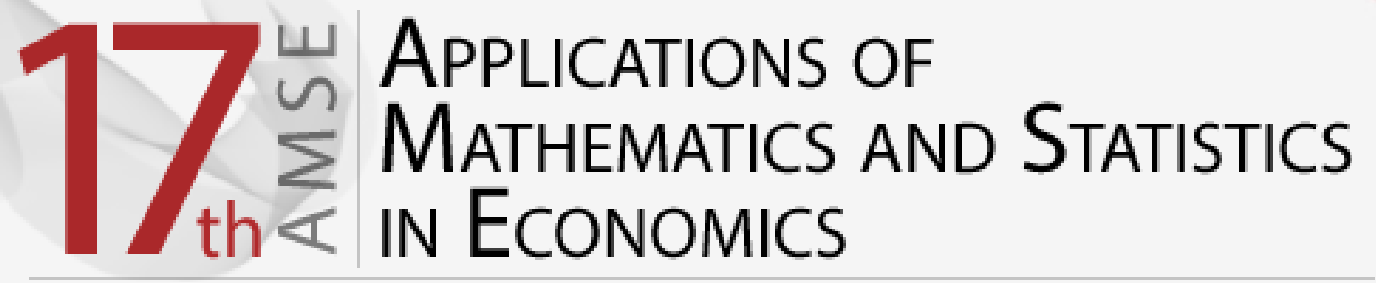

International Scientific Conference | Poland • 27-31 August 2014 
Scientific Committee

Richard Hindls, Stanislava Hronová, Rudolf Zimka, Walenty Ostasiewicz, Emília Zimková, Zofia Rusnak, Martin Bod'a

Organizing Committee

Beata Zmyślona, Cyprian Kozyra, Grzegorz Rogoziński, Kristýna Vltavská

\section{Reviewers}

Milan Bašta, Diana Bílková, Martin Bod'a, Joanna Dębicka, Tomáš Fiala, Jakub Fischer, Stanisław Heilpern, Karel Helman, Lenka Hudrlíková, Miroslav Hužvár, Nikola Kaspř́ková, Alena Kaščáková, Kamil Kladívko, Jindřich Klůfa, Pavol Král', Katarzyna Kuziak, Jana Langhamrová, Ivana Malá, Tomáš Marcinko, Luboš Marek, Miloš Maryška, Petr Mazouch, Zofia Mielecka-Kubień, Witold Miszczak, Petr Musil, Gabriela Nedelová, Walenty Ostasiewicz, Iva Pecáková, Viera Roháčová, Zofia Rusnak, Mária Stachová, Jana Špirková, Šárka Šustová, Jana Tepperová, Vladimír Úradníček, Kristýna Vltavská, Michal Vrabec, Dariusz Wawrzyniak, Henryk Zawadzki, Jaroslav Zbranek, Tomáš Zeithamer, Martin Zelený, Jan Zeman, Rudolf Zimka, Emília Zimková, Pavel Zimmermann, David Žižka

Layout

Martin Bod'a, Beata Zmyślona, Grzegorz Rogoziński

Front page design

Grzegorz Rogoziński

CD cover design

Beata Dębska

Articles published in the form submitted by the authors

All rights reserved. No part of this book may be reproduced in any form or in any means without the prior permission in writing of the Publisher

(C) Copyright by Wrocław University of Economics Wrocław 2014

ISBN 978-83-7695-421-9

Wydawnictwo Uniwersytetu Ekonomicznego we Wrocławiu

53-345 Wrocław, ul. Komandorska 118/120 www.ue.wroc.pl

Sprzedaż książek tel./fax 71 36-80-602

e-mail: econbook@ue.wroc.pl www.ksiegarnia.ue.wroc.pl 


\section{Contents}

Foreword

Diana Bílková: TL-Moments: Analogy of Classical L-Moments

Dagmar Blatná: Application of Robust Regression in the Analysis of Internet Access in European Countries

Martin Bod’a, Mária Kanderová: Rebalancing Issues in Tracking Error Variance Minimization

Martin Bod'a, Viera Roháčová: Application of Six Sigma Ideas to Timing Decisions at Financial Markets

Anton Dekrét, Rudolf Zimka: On the Price Hartwick's Task and Its Inverse in a Dynamic Model of an Economy with Exhaustible Resources

Joanna Dębicka, Agnieszka Marciniuk: Comparison of Reverse Annuity Contract and Reverse Mortgage on the Polish Market.

Petra Dotlačilová, Jitka Langhamrová: The Influence of Mortality Models for the Expected Future Life-time of Older People

Marek Ďurica, Lucia Švábová: Delta and Gamma for Chooser Options.

Vlastimil Farkašovský: New Concept of Pension Funds Performance Evaluation

Albert Gardon: The Normality of Weekly Relative Changes of the Freight Rate in Container Shipping.

Mária Grausová, Miroslav Hužvár, Jana Štrangfeldová: Healthcare Systems Efficiency in the Visegrád Group.

Stanisław Heilpern: Multiple Life Insurance - Pension Calculation

Alena Kaščáková, Gabriela Nedelová: Changes in Slovak Households' Economy

Igor Kollár, Pavol Král', Peter Laco: Methodology for Assessing Website Improvement in Corporate Environment.

Maciej Kostrzewski: Some Method of Detecting the Jump Clustering Phenomenon in Financial Time Series.

Cyprian Kozyra, Beata Zmyślona, Katarzyna Madziarska: Complementary Objective and Subjective Measures of Hospital Services Quality...

Pavol Král', Mária Stachová, Lukáš Sobíšek: Utilization of Repeatedly Measured Financial Ratios in Corporate Financial Distress Prediction in Slovakia

Ivana Malá: The Use of Finite Mixture Model for Describing Differences in Unemployment Duration

Lukáš Malec: Studying Economics and Tourism Industry Relations by Smooth Partial Least Squares Method Depending on Parameter. 
Tomáš Marcinko: Consequences of Assumption Violations Regarding Classical Location Tests.

Edyta Mazurek: The Income Tax Progression Depending on Social Insurance Contribution in Poland.

Petr Musil, Jana Kramulová, Jan Zeman: Regional Consumption Expenditures: An Important Starting Point for Regional Input-output Tables.

Katarzyna Ostasiewicz, Walenty Ostasiewicz: Good Life: From Political to Human Economy

Anna Sączewska-Piotrowska: Analysis of Poverty Transitions in Poland Using Multilevel Discrete-Time Event History Models

Martina Šimková, Petra Švarcová: Disadvantaged University Students in the Czech Republic.

Michal Široký: The Use of Short-term Business Statistics for Quarterly GDP Flash Estimates in the Czech Republic

Zdeněk Šulc, Hana Řezanková: Evaluation of Recent Similarity Measures for Categorical Data.

Lucia Švábová, Marek Ďurica: The Relationship Between the Finite Difference Method and Trinomial Trees

Kristýna Vltavská, Jaroslav Sixta: The Estimation of Final Consumption Expenditures

Lenka Vraná: Business Cycle Analysis: Tracking Turning Points

Janusz Wywiał: On Bayesian Testing in Auditing

Emília Zimková: Window Analysis of Supper-efficiency Change: Case of the Slovak Banking System ....

Beata Zmyślona: Statistical Modelling of the Impact of Diabetes on the Risk of Hospitalization 


\title{
EVALUATION OF RECENT SIMILARITY MEASURES FOR CATEGORICAL DATA
}

\author{
ZDENĚK ŠULC, HANA ŘEZANKOVÁ \\ University of Economics, Prague, Faculty of Informatics and Statistics, \\ Department of Statistics and Probability, W. Churchill Sq. 4, 13067 Prague 3, Czech Republic \\ email: zdenek.sulc@vse.cz, hana.rezankova@vse.cz
}

\begin{abstract}
This paper evaluates recently introduced similarity measures which are based on new approaches and have been proposed for purposes of hierarchical clustering of categorical data. Clustering with these similarity measures is compared to clustering with the simple matching coefficient, and further to alternative methods of categorical data clustering, namely, two-step cluster analysis and latent class analysis. Cluster analysis is applied to economic data. Quality of obtained clusters is evaluated by several indices, which include the normalized Gini coefficient and the normalized entropy, the modified pseudo F indices based on the Gini coefficient and the entropy. The results indicate that clustering with some of recently introduced similarity measures and alternative methods provide better clusters than in case of standardly used simple matching coefficient.
\end{abstract}

Key words: similarity measures, categorical data, cluster analysis.

DOI: 10.15611/amse.2014.17.27

\section{Introduction}

Cluster analysis is one of important multivariate statistical methods. It is widely used, e.g. in the data analysis from questionnaire surveys, where it helps to identify segments of respondents. Its principle is based on dividing of an examined dataset into several groups according to similarity (or distance) of objects in these groups. When examining a dataset with quantitative variables, the similarity (or distance) measures are well known and they are standardly implemented in statistical software. Different situation occurs when dealing with categorical (nominal) data. There are only several standardly used similarity measures. The best-known is the simple matching coefficient, also known as the overlap measure, which does not provide good results. There have been proposed many similarity measures for categorical data in recent years; however, none of them was examined properly.

The aim of this paper is to evaluate the clustering with recently introduced similarity measures and compare it to clustering with the simple matching coefficient and further to alternative methods for categorical data clustering, namely, two-step cluster analysis and latent class analysis. Unlike previous reviews, e.g. (Boriah et al., 2008), this paper also compares other than hierarchical methods of clustering. Moreover, different evaluation criteria, which is based on within-cluster variability, are applied for evaluation of clustering results. For the analysis, the data from the EU-SILC survey, which was held in 2011, have been used. Particularly, Czech and Slovak households are going to be compared in their structure. The quality of final clusters is going to be evaluated from a point of view of both within-cluster variability and their economic interpretation. 


\section{Similarity Measures and Methods for Categorical Data Clustering}

In this paper, the following similarity measures are going to be evaluated: Eskin, IOF, Lin, $S 2$ and the simple matching coefficient. These measures are applied in hierarchical clustering with the complete linkage method. Moreover, the data are analyzed by two-step cluster analysis and latent class analysis. All formulas in this paper, apart from $S 2$ formula, are based on data matrix $\mathbf{X}=\left[x_{i c}\right]$, where $i=1,2, \ldots, n$ ( $n$ is the total number of objects); $c=1,2, \ldots, m$ ( $m$ is the total number of variables).

\subsection{Simple Matching Coefficient}

The simple matching coefficient (hereinafter the overlap measure) represents the simplest way for measuring of similarity. When determining the similarity between objects $\mathbf{x}_{i}$ and $\mathbf{x}_{j}$, it takes the value 1 for the $c$-th variable in case the objects match and the value 0 otherwise. It is described by the formula

$$
S_{c}\left(x_{i c}, x_{j c}\right)=\left\{\begin{array}{l}
1 \text { if } x_{i c}=x_{j c} \\
0 \text { otherwise }
\end{array} .\right.
$$

The similarity measure between two objects is then computed as

$$
S\left(\mathbf{x}_{i}, \mathbf{x}_{j}\right)=\frac{\sum_{c=1}^{m} S_{c}\left(x_{i c}, x_{j c}\right)}{m} .
$$

Every similarity measure can be expressed as a dissimilarity measure. In case of the overlap measure, the relationship is given by the expression

$$
D\left(\mathbf{x}_{i}, \mathbf{x}_{j}\right)=1-S\left(\mathbf{x}_{i}, \mathbf{x}_{j}\right) .
$$

The overlap measure is wildly used because of its simplicity. On the other hand, this measure neglects important characteristics in a dataset, such a number of categories or frequencies of categories of a given variable. These characteristics can serve for better formulation of similarity between given objects. Recently introduced measures try to deal with this drawback.

\subsection{Recent Similarity Measures}

The Eskin measure was proposed by Eskin et al. (2002). Its basic idea is to assign higher weights to mismatches by variables with the higher number of categories. The similarity between two objects for the $c$-th variable is then expressed as

$$
S_{c}\left(x_{i c}, x_{j c}\right)=\left\{\begin{array}{l}
1 \text { if } x_{i c}=x_{j c} \\
\frac{n_{c}^{2}}{n_{c}^{2}+2} \text { otherwise }
\end{array}\right.
$$

where $n_{c}$ is a number of categories of the $c$-th variable. Equation (2) can be used for computation of the similarity between two objects. The dissimilarity measure is computed as 


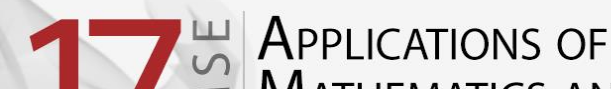

$$
D\left(\mathbf{x}_{i}, \mathbf{x}_{j}\right)=\frac{1}{S\left(\mathbf{x}_{i}, \mathbf{x}_{j}\right)}-1 .
$$

The inverse occurrence frequency $(I O F)$ treats mismatches of more frequent categories by lower weights, i.e.

$$
S_{c}\left(x_{i c}, x_{j c}\right)=\left\{\begin{array}{l}
1 \text { if } x_{i c}=x_{j c} \\
\frac{1}{1+\ln f\left(x_{i c}\right) \cdot \ln f\left(x_{j c}\right)} \text { otherwise }
\end{array}\right.
$$

where $f\left(x_{i c}\right)$ expresses a frequency of the value $x_{i c}$ of the $c$-th variable. The similarity and dissimilarity measure can be computed by using Equations (2) and (5).

The Lin measure, which was introduced by Lin (1998), assigns higher weights to more frequent categories in case of matches and lower weights to less frequent categories in case of mismatches, i.e.

$$
S_{c}\left(x_{i c}, x_{j c}\right)=\left\{\begin{array}{l}
2 \cdot \ln p\left(x_{i c}\right) \text { if } x_{i c}=x_{j c} \\
2 \cdot \ln \left(p\left(x_{i c}\right)+p\left(x_{j c}\right)\right) \text { otherwise }
\end{array}\right.
$$

where $p\left(x_{i c}\right)$ expresses a relative frequency of the value $x_{i c}$ of the $c$-th variable. The similarity measure between two objects is computed as

$$
S\left(\mathbf{x}_{i}, \mathbf{x}_{j}\right)=\frac{\sum_{c=1}^{m} S_{c}\left(x_{i c}, x_{j c}\right)}{\sum_{c=1}^{m}\left(\ln p\left(x_{i c}\right)+\ln p\left(x_{j c}\right)\right)}
$$

and the dissimilarity measure according to Equation (5).

The $S 2$ measure was proposed by Morlini and Zani (2012) and it is based on a different approach than the previous measures. For its computation a transformation of the initial matrix $\mathbf{X}=\left[x_{i c}\right]$ is needed. If the $c$-th variable has at least two categories, $K_{c} \geq 2$, then for each category one dummy variable is created. The total number of variables in the newly arisen matrix can be computed as a sum of $K_{c}$ over $m$ original variables. The similarity measure can be computed by using the formula

$$
S\left(\mathbf{x}_{i}, \mathbf{x}_{j}\right)=\frac{\sum_{c=1}^{m} \sum_{u=1}^{K_{c}} \tau(i, j)_{c u} \ln \left(\frac{1}{f_{c u}^{2}}\right)}{\sum_{c=1}^{m} \sum_{u=1}^{K_{c}} \tau(i, j)_{c u} \ln \left(\frac{1}{f_{c u}^{2}}\right)+\sum_{c=1}^{m} \phi(i, j)_{c} \sum_{u=1}^{K_{c}} f_{c u} \ln \left(\frac{1}{f_{c u}^{2}}\right)},
$$

where $u=1,2, \ldots K_{c}$ is an index of the $u$-th dummy variable of the $c$-th original variable, $f_{c u}{ }^{2}$ is the second power of the frequency of the $u$-th category of the original $c$-th variable. When using Equation (9), the following conditions have to be held: 


$$
\begin{gathered}
\tau(i, j)_{c u}=1 \text { if } x_{i c u}=1 \text { and } x_{j c u}=1, \\
\tau(i, j)_{c u}=0 \text { otherwise, } \\
\phi(i, j)_{c}=1 \text { if } x_{i c u}=1 \cap x_{j c t}=1 \text { and } x_{i c t}=1 \cap x_{j c u}=0, \text { for } u \neq t, \\
\phi(i, j)_{c}=0 \text { otherwise. }
\end{gathered}
$$

The $S 2$ measure takes values from 0 to 1 , where 1 indicates maximal similarity, i.e. both objects are identical. The system of weights, which is based on the information theory, assigns higher importance to rarely observed values.

\subsection{Methods of Cluster Analysis}

The similarity measures, which have been introduced above, can be applied in hierarchical cluster analysis. It is based on a proximity matrix, which contains distances among all objects in the dataset. At the beginning, each case is a cluster of its own. Then, in each step, two nearest clusters are merged into a new one. Therefore, the definition of distance between clusters is a very important part of the analysis. For the purpose of this paper, the complete linkage method has been used. In this method, distance between two clusters is defined as the distance between two furthest objects from the considered clusters.

An alternative way to categorical data clustering is based on the log-likelihood distance. On the contrary to previously mentioned measures, this measure is used in two-step cluster analysis (2STEP), which is implemented in the statistical software IBM SPSS Statistics. Its algorithm consists of two steps. In the first one, preliminary clusters are created sequentially. In the second step, the clustering algorithms are applied to the preliminary clusters. The full description of two-step cluster analysis can be found in (SPSS, Inc., 2014). The advantages of this method include the ability to cluster both quantitative and categorical data. Also, this method is much less time consuming in a comparison to standard hierarchical analysis, especially in case of larger datasets. On the other hand, the created clusters depend on the initial object order. Therefore, it is recommended to order objects randomly before the start of an analysis.

Another approach to categorical data clustering represents latent class analysis (LCA), which is based on a latent variable consisting of discrete and mutually exclusive latent classes. This latent variable can only be measured indirectly by using two or more observable (also manifest) categorical variables. For each object, the probability of belonging to each latent class is then computed. The object is assigned into the latent class with the highest probability.

Two-step cluster analysis and latent class analysis are complex methods. Both enable to adjust a lot of parameters, so their final clusters might differ. Because these methods are not the primary aim of the research, they serve for reference purposes only, the standard setting of all their parameters were used.

\section{Evaluation Criteria of Clusters}

The quality of final clusters is going to be evaluated by using indices based on withincluster variability and by the modified pseudo $F$ indices, which are explained e.g. in (̌̌ezanková et al., 2011). 


\section{7.

The within-cluster variability is an important indicator of cluster quality. With the increasing number of clusters, the within-cluster variability decreases. Clustering with a certain similarity measure with the greatest degrease is considered to be the best, because its clusters are the most homogenous. The normalized Gini coefficient and the normalized entropy have been chosen for purposes of determining the within-cluster variability.

The Gini coefficient, also known as the nomvar, measures the variability of nominal variables. For the $c$-th variable in the $g$-th cluster $(g=1,2, \ldots, k)$ it can be expressed as

$$
G_{g c}=1-\sum_{u=1}^{K_{c}}\left(\frac{n_{g c u}}{n_{g}}\right)^{2},
$$

where $n_{g}$ is a number of objects in the $g$-th cluster, $n_{g c u}$ is a number of objects in the $g$-th cluster by the $c$-th variable with the $u$-th category $\left(u=1,2, \ldots, K_{c} ; K_{c}\right.$ is a number of categories of the $c$-th variable). The normalized within-cluster variability for $k$ cluster solution based on the Gini coefficient for $m$ variables can be expressed as

$$
\operatorname{Gnorm}(k)=\sum_{g=1}^{k} \frac{n_{g}}{n \cdot m} \sum_{c=1}^{m} \frac{K_{c}}{K_{c}-1} G_{g c},
$$

which takes values from 0 to 1 , where lower values indicate more homogenous clusters.

An alternative way to express the variability is the entropy, which can be expressed (for the $c$-th variable in the $g$-th cluster, $n_{g c u}>0$ ) as

$$
H_{g c}=-\sum_{u=1}^{K_{c}}\left(\frac{n_{g c u}}{n_{g}} \ln \frac{n_{g c u}}{n_{g}}\right) .
$$

To get within-cluster variability for $k$ clusters, the normalized entropy can be used:

$$
\operatorname{Hnorm}(k)=\sum_{g=1}^{k} \frac{n_{g}}{n \cdot m} \sum_{c=1}^{m} \frac{H_{g c}}{\ln K_{c}} .
$$

The pseudo $F$ indices were developed to determine an optimal number of clusters. They are based on the F statistic. A cluster solution with the highest value of this statistics is considered to be the best.

For $k$-cluster solution, the pseudo $F$ index based on the Gini coefficient has the formula

$$
\operatorname{PSFG}(k)=\frac{(n-k)(G(1)-G(k))}{(k-1) G(k)},
$$

where $G(1)$ expresses variability in the whole dataset and $G(k)$ evaluates within-cluster variability in the $k$-cluster solution, both based on the Gini coefficient.

The pseudo F coefficient based on the entropy is defined by the formula

$$
\operatorname{PSFH}(k)=\frac{(n-k)(H(1)-H(k))}{(k-1) H(k)},
$$

where $H(1)$ is the entropy in the whole dataset and $H(k)$ the within-cluster entropy in the $k$-cluster solution. 


\section{Application to Economic Data}

In this paper, data from the EU-SILC (European Union - Statistics on Income and Living Conditions) survey, held in 2011, were used. The aim of the analysis is to compare the structure of the Czech and Slovak households from a point of view of their financial possibilities and used durables. Studies of the Czech and Slovak households with respect to material deprivation and poverty were published e.g. by Bartošová and Želinský (2013), Želinský (2012). Cluster analyses of the Czech households according to some durables were applied in (Řezanková and Löster, 2013). Six following categorical variables were used for the purpose of this paper; their categories are displayed in brackets: Capacity to afford paying for one week annual holiday away from home [yes, no], Capacity to afford a meal with meat, chicken, fish (or vegetarian equivalent) every second day [yes, no], Capacity to face unexpected financial expenses [yes, no], Do you have a computer [yes, no-cannot afford, no - other reason], Do you have a car [yes, no - cannot afford, no - other reason], Ability to make ends meet [with great difficulty, with difficulty, with some difficulty, fairly easily, easily, very easily]. In total, the data come from 8866 Czech and 5193 Slovak households.

The analysis consists of two steps. In the first one, the clusters of households are going to be computed and evaluated according to measures and methods, which were introduced in Section 2. In the second step, the final clusters created with selected measures and methods are going to be evaluated from a point of view of their economic interpretation.

The similarity measures, which have been introduced in Section 2, are not part of statistical systems, so they had to be programmed in the Matlab software. The proximity matrices based on particular similarity measure have been processed in IBM SPSS Statistics. The complete linkage method has been used. The entire two-step cluster analysis was performed in IBM SPSS Statistics and latent class analysis in the LatentGold software. Solutions for two to six clusters have been computed. At the end, the evaluation criteria have been computed using the Matlab software for all the measures and the methods.

\subsection{Czech Household Data}

Table 1 summarizes evaluation criteria for clustering with individual similarity measures and for the other methods based on the Czech household data. The quality of a particular cluster solution can be evaluated according to the within-cluster variability. The faster decrease of within-cluster variability, the more homogenous clusters are. The fastest decrease of variability is by the Eskin measure; its variability decreases from 0.803 to 0.387 according to the Gnorm measure and from 0.815 to 0.376 according to the Hnorm measure. Throughout all cluster solutions of the Eskin measure, the variability is smaller in a comparison to other approaches of clustering. That means that clustering using this measure provides the best cluster solutions. It is followed by the IOF measure, which also performs very well. The overlap measure, which is commonly used, ends up on the third place, with a significant distance from the first two measures. It is closely followed by the last two measures Lin and $S 2$. Both reference methods, $2 S T E P$ and $L C A$, have the results in the middle of the range. They would have been placed behind the IOF measure in the following order: $L C A$ and 2STEP.

According to the optimal number of clusters, which is marked boldly, the most of similarity measures and methods prefer the two-cluster solution. There are two exceptions 


\section{7. \\ Mathematics and Statistics \\ IN ECONOMICS}

International Scientific Conference | Poland • 27-31 August 2014

though; the overlap measure prefers five-cluster solution and the $S 2$ measure three- or fourcluster solutions.

Table 1. Evaluation criteria for clustering with examined similarity measures and for other methods for the Czech household data

\begin{tabular}{|c|c|c|c|c|c|c|c|}
\hline & \# of clusters & 1 & 2 & 3 & 4 & 5 & 6 \\
\hline \multirow{4}{*}{ Overlap } & Gnorm & 0.803 & 0.756 & 0.630 & 0.606 & 0.513 & 0.494 \\
\hline & Hnorm & 0.815 & 0.768 & 0.650 & 0.619 & 0.516 & 0.495 \\
\hline & PSFG & & 464.117 & 1002.785 & 814.930 & 1034.185 & 926.993 \\
\hline & PSFU & & 434.004 & 835.242 & 727.061 & 977.649 & 881.846 \\
\hline \multirow{4}{*}{ Eskin } & Gnorm & 0.803 & 0.562 & 0.494 & 0.439 & 0.433 & 0.387 \\
\hline & Hnorm & 0.815 & 0.572 & 0.494 & 0.433 & 0.426 & 0.376 \\
\hline & PSFG & & 3023.718 & 2133.429 & 1834.565 & 1408.003 & 1372.450 \\
\hline & PSFH & & 2680.094 & 1930.558 & 1647.784 & 1269.836 & 1222.209 \\
\hline \multirow{4}{*}{ IOF } & Gnorm & 0.803 & 0.562 & 0.495 & 0.438 & 0.437 & 0.397 \\
\hline & Hnorm & 0.815 & 0.572 & 0.495 & 0.433 & 0.431 & 0.391 \\
\hline & PSFG & & 3023.72 & 2129.03 & 1837.92 & 1385.53 & 1384.18 \\
\hline & PSFH & & 2680.09 & 1919.72 & 1649.82 & 1248.20 & 1252.12 \\
\hline \multirow{4}{*}{ Lin } & Gnorm & 0.803 & 0.691 & 0.680 & 0.587 & 0.534 & 0.509 \\
\hline & Hnorm & 0.815 & 0.691 & 0.675 & 0.586 & 0.523 & 0.499 \\
\hline & PSFG & & 1177.471 & 675.170 & 1009.432 & 1057.670 & 979.813 \\
\hline & PSFH & & 1149.231 & 718.234 & 1013.031 & 1125.325 & 1033.066 \\
\hline \multirow{4}{*}{$\mathrm{S} 2$} & Gnorm & 0.803 & 0.724 & 0.649 & 0.586 & 0.549 & 0.543 \\
\hline & Hnorm & 0.815 & 0.740 & 0.671 & 0.612 & 0.581 & 0.573 \\
\hline & PSFG & & 1082.297 & 1254.480 & 1278.702 & 1227.871 & 1024.126 \\
\hline & PSFH & & 1277.676 & 1455.767 & 1452.600 & 1372.480 & 1157.129 \\
\hline \multirow{4}{*}{ 2STEP } & Gnorm & 0.803 & 0.565 & 0.521 & 0.462 & 0.441 & 0.417 \\
\hline & Hnorm & 0.815 & 0.585 & 0.527 & 0.465 & 0.446 & 0.421 \\
\hline & PSFG & & 3074.066 & 2048.426 & 1872.780 & 1629.937 & 1500.663 \\
\hline & PSFH & & 2739.283 & 1969.637 & 1791.560 & 1597.424 & 1477.998 \\
\hline \multirow{4}{*}{ LCA } & Gnorm & 0.803 & 0.563 & 0.507 & 0.467 & 0.428 & 0.420 \\
\hline & Hnorm & 0.815 & 0.586 & 0.533 & 0.483 & 0.456 & 0.431 \\
\hline & PSFG & & 3106.425 & 2242.338 & 1885.550 & 1728.027 & 1445.836 \\
\hline & PSFH & & 2750.016 & 1984.105 & 1741.828 & 1493.459 & 1358.503 \\
\hline
\end{tabular}

In the second step of the analysis, the final clusters are going to be evaluated from a point of view of the economic interpretation. For this comparison, the best five cluster solutions have been chosen according to their quality in the first step: Eskin, IOF, LCA, 2STEP and overlap.

In the two-cluster solution, clustering with the use of both Eskin and IOF measures provide the exactly same results. Households are separated into two groups, wealthier (58\%) and poorer $(42 \%)$. When creating the clusters, the key importance has the variable Capacity to face unexpected financial expenses. All answers yes to this question are assigned into the first cluster and all answers no into the second one. The three cluster solution is very interesting in case of the Eskin measure. The newly created cluster contains households, which cannot afford a holiday, but they have capacity to face unexpected financial expenses. These 
households are moderately wealthy; however, they cannot spend their financial reserves on unnecessary expenses.

The two-cluster solution, provided by $L C A$, differentiates pretty well between wealthier $(57 \%)$ and poorer $(43 \%)$ households. Interesting results are provided by the three-cluster solution as well. The cluster of poorer households has been further separated into other two groups. One describes poor households and the other one the households which are little bit wealthier, but they do not own a car or a computer from other reasons. It would be interesting to describe this group of households in detail; however, the data from the EU-SILC survey does not allow it.

2STEP has the most similar clusters according their size. The ratio of wealthier households is $54 \%$ and the poorer ones $46 \%$. However, their differentiation is worse than by LCA. Its three-cluster solution can be interpreted in a similar way as by $L C A$, but again, the differentiation is much poorer.

The clusters, which come from the overlap measure, are very unbalanced (wealthier households occupy $85 \%$ of objects and poorer ones $15 \%$ ). Moreover, the boundary between the clusters is very fuzzy, which makes them the most inappropriate of all examined ones.

Although the resulting clusters of $L C A$ have not been considered as the best in the first step of analysis, they have proven their quality when confronted to their interpretation, which has been the best among all measures and methods, in the second step.

\subsection{Slovak Household Data}

Table 2 contains evaluation criteria for the Slovak household data analyses. Similarly to the results based on Czech data, clustering with the Eskin measure provides generally the best results across all other measures and methods. However, the $I O F$ measure has the best results in two-cluster solution, which proves to be the optimal one for almost all measures, except for the Lin measure. On the whole, when dealing with all measures and methods together, their order is following: Eskin, 2STEP, IOF, LCA, Lin, overlap and $S 2$.

In the second step of the analysis, the same measures and methods as for the Czech households are going to be examined. The two-cluster solution of the Eskin measure creates two groups of households, which could be considered as wealthier (64\%) and poorer (36\%). The differentiation is poorer than by the Czech households. The three-cluster solution of this measure behaves in the same way as in the Czech household data, i.e. it contains households, which cannot afford a holiday, but have capacity to face unexpected financial expenses.

The IOF measure has very good results in the two-cluster solution. It assigns $56 \%$ of Slovak household to be wealthier and $44 \%$ to be poorer. Thus, the clusters are of similar size and their differentiation is also good.

Despite the good results in the first part of analysis, 2 STEP does not provide very good clusters on this dataset. The two-cluster solution separates the households into wealthier (45\%) and poorer (55\%). The classification is not as good as by the Eskin measure or LCA.

$L C A$ provides very good clusters in the two-cluster solution, they are even better than clusters provided by the Eskin measure. There is $56 \%$ of wealthier households and $44 \%$ of poorer in Slovakia. In the same way as in case of the Czech households, the three-cluster solution also separates the households which do not own durables from other reasons.

The final clusters provided by the overlap measure are slightly better than in case of the Czech households, but still, they are very insufficient because of their poor differentiation. The ratio of the wealthier households is $65 \%$ and the poorer ones $35 \%$. 


\section{7. \\ Mathematics and Statistics \\ IN ECONOMICS}

International Scientific Conference | Poland • 27-31 August 2014

Table 2. Evaluation criteria for clustering with examined similarity measures and for other methods for the Slovak household data

\begin{tabular}{llrrrrrr}
\hline & \# of clusters & \multicolumn{1}{l}{2} & \multicolumn{1}{c}{3} & \multicolumn{1}{c}{4} & \multicolumn{1}{c}{5} \\
\hline \multirow{5}{*}{ Overlap } & Gnorm & 0.846 & 0.669 & 0.642 & 0.563 & 0.534 & 0.500 \\
& Hnorm & 0.855 & 0.682 & 0.657 & 0.581 & 0.556 & 0.518 \\
& PSFG & & $\mathbf{1 2 1 3 . 7 9 9}$ & 741.611 & 751.705 & 650.874 & 609.457 \\
& PSFU & & $\mathbf{1 1 2 3 . 8 3 7}$ & 685.808 & 669.065 & 567.443 & 530.676 \\
\hline \multirow{5}{*}{ Eskin } & Gnorm & 0.846 & 0.630 & 0.516 & 0.448 & 0.419 & 0.387 \\
& Hnorm & 0.855 & 0.640 & 0.517 & 0.449 & 0.418 & 0.384 \\
& PSFG & & $\mathbf{1 4 3 9 . 1 6 8}$ & 1296.432 & 1163.495 & 981.570 & 893.556 \\
& PSFH & & $\mathbf{1 2 6 8 . 9 3 9}$ & 1152.934 & 1012.660 & 848.886 & 766.809 \\
\hline \multirow{5}{*}{ IOF } & Gnorm & 0.846 & 0.605 & 0.566 & 0.548 & 0.457 & 0.453 \\
& Hnorm & 0.855 & 0.612 & 0.566 & 0.548 & 0.457 & 0.453 \\
& PSFG & & $\mathbf{1 6 8 3 . 5 7 2}$ & 1028.116 & 767.786 & 858.245 & 699.469 \\
& PSFH & & $\mathbf{1 4 9 9 . 9 4 3}$ & 936.213 & 699.588 & 753.724 & 617.284 \\
\hline \multirow{5}{*}{ Lin } & Gnorm & 0.846 & 0.785 & 0.635 & 0.610 & 0.578 & 0.484 \\
& Hnorm & 0.855 & 0.795 & 0.649 & 0.620 & 0.584 & 0.477 \\
& PSFG & & 426.171 & $\mathbf{8 0 8 . 0 4 5}$ & 639.165 & 585.180 & 709.009 \\
& PSFH & & 415.071 & $\mathbf{7 5 3 . 8 0 9}$ & 632.024 & 595.899 & 728.655 \\
\hline \multirow{5}{*}{ S2 } & Gnorm & 0.846 & 0.752 & 0.732 & 0.629 & 0.592 & 0.587 \\
& Hnorm & 0.855 & 0.762 & 0.740 & 0.653 & 0.626 & 0.621 \\
& PSFG & & $\mathbf{7 3 2 . 1 9 9}$ & 453.244 & 699.282 & 671.351 & 552.808 \\
& PSFH & & $\mathbf{8 5 5 . 5 8 5}$ & 554.863 & 786.693 & 727.244 & 600.372 \\
\hline \multirow{5}{*}{ LCSTEP } & Gnorm & 0.846 & 0.609 & 0.542 & 0.500 & 0.455 & 0.429 \\
& Hnorm & 0.855 & 0.620 & 0.557 & 0.506 & 0.466 & 0.446 \\
& PSFG & & $\mathbf{1 6 7 4 . 9 6 3}$ & 1281.085 & 1072.374 & 1008.041 & 946.544 \\
& PSFH & & $\mathbf{1 5 0 7 . 7 0 7}$ & 1154.575 & 1010.648 & 941.556 & 884.983 \\
\hline & Gnorm & 0.846 & 0.611 & 0.556 & 0.496 & 0.475 & 0.454 \\
& Hnorm & 0.855 & 0.631 & 0.578 & 0.517 & 0.498 & 0.475 \\
& PSFG & & $\mathbf{1 7 0 8 . 6 9 4}$ & 1220.549 & 1127.542 & 933.846 & 825.988 \\
& PSFH & & $\mathbf{1 5 3 5 . 6 0 5}$ & 1109.201 & 1030.682 & 843.284 & 749.679 \\
\hline
\end{tabular}

\section{Conclusion}

In this paper, six similarity measures for categorical data clustering were evaluated. Clustering performance with these measures was compared to the performance of two alternative methods for categorical data clustering. There were two main fields of comparison. Firstly, the final cluster solutions of measures and methods were compared from a point of view of within-cluster variability; secondly, from a point of view of the economic interpretation. The Czech and Slovak household data from survey EU-SILC 2011 were used.

In both datasets, the best clusters were provided by hierarchical clustering with the Eskin measure from a point of view of the within-cluster variability. The order of other measures and methods differs. In the Czech household dataset it is: IOF, LCA, 2STEP, overlap, Lin and $S 2$, whereas in the Slovak household dataset it is $2 S T E P, I O F, L C A, L i n$, overlap and $S 2$. The order is not surprising; in some our previous researches, e.g. in (Šulc, 2014), the similarity measures Eskin and IOF performed very well in datasets with the simple structure similar to the one used in this paper. 
In the second part of the analysis, the examined measures and methods were evaluated from a point of view of their economic interpretation. In both datasets, latent class analysis differentiated the wealthier and poorer households at the best. According to this method, the ratio of wealthier and poorer households in the Czech Republic and in Slovakia is almost the same. Good results were also provided by the Eskin and the IOF measures. When comes to three-cluster solution, only clusters provided by the Eskin measure and LCA have the economic interpretation. On a basis of the findings presented in the paper, one might recommend the use of $L C A$ for clustering the EU-SILC data and similar surveys. The use of the complete linkage method with the Eskin measure can be considered as a good alternative.

\section{Acknowledgements}

This work was supported by the University of Economics, Prague under Grant IGA F4/104/2014 and by the Slovak Scientific Grant Agency as part of the research project VEGA 1/0127/11 Spatial Distribution of Poverty in the European Union. The EU-SILC datasets were made available for the research on the basis of contract no. EU-SILC/2011/33, signed between the European Commission, Eurostat, and the Technical University of Kosice. Eurostat has no responsibility for results and conclusions which are those of the researcher. The authors would like to thank to Adam Mohammad for his advice on the Matlab software.

\section{References}

1. BARTOŠOVÁ, J., ŽELINSKÝ, T. 2013. The extent of poverty in the Czech and Slovak Republic 15 years after the split. In Post-Communist Economies, 2013, vol. 25, iss. 1, pp. 119-131.LE, S. Q., HO, T. B. 2005. An association-based dissimilarity measure for categorical data. In Pattern Recognition Letters, 2005, vol. 26, iss. 16, pp. 2549-2557.

2. BORIAH, S., CHANDOLA, V., and KUMAR, V. 2008. Similarity measures for categorical data: A comparative evaluation. In Proceedings of the 8th SIAM International Conference on Data Mining, SIAM, pp. 243-254.

3. ESKIN, E., ARNOLD, A., PRERAU, M., PORTNOY, L., STOLFO, S., V. 2002. A geometric framework for unsupervised anomaly detection. In D. Barbará and S. Jajodia, editors, Applications of Data Mining in Computer Security, pp. 78-100.

4. LIN, D. 1998. An information-theoretic definition of similarity. In ICML '98: Proceedings of the 15th International Conference on Machine Learning. San Francisco : Morgan Kaufmann Publishers Inc., 1998, pp. 296-304.

5. MORLINI, I., ZANI, S. 2012. A new class of weighted similarity indices using polytomous variables. In Journal of Classification, 2012, vol. 29, iss. 2, pp. 199-226.

6. ŘEZANKOVÁ, H., LÖSTER, T. 2013. Cluster analysis of households characterized by categorical indicators. In Ekonomie a Management, 2013, vol. 16, iss. 3, pp. 139-147.

7. ̌̌EZANKOVÁ, H., LÖSTER, T., HÚSEK, D. 2011. Evaluation of categorical data clustering. In Advances in Intelligent Web Mastering 3. Berlin : Springer Verlag, 2011, pp. 173-182.

8. SPSS, Inc. 2014. Help. Chicago, IL : SPSS, Inc., 2014.

9. ŠULC, Z. 2014. Porovnání nových přístupů ve shlukování nominálních dat. In Sborník prací vědeckého semináře doktorského studia FIS VŠE. Praha : Oeconomica, 2014, pp. 214-223.

10. ŽELINSKÝ, T. 2012. Changes in Relative Material Deprivation in Regions of Slovakia and the Czech Republic. In Panoeconomicus, 2012, vol. 59, iss. 3, pp. 335-353. 